\title{
COVID-19: Naming Process and the Mechanism Behind Stigmatisation
}

\author{
${ }^{1}$ Jurong Country Garden School, Zhenjiang, China \\ wange.li@outlook.com
}

Wange $\mathrm{Li}^{1}$,

\begin{abstract}
This paper considers the development of naming process of COVID-19 pandemic and its interaction with the mechanism of stigmatisation formed toward certain groups. The majority of data collected were from online newspapers, mass social medias and Chinese we-medias. I have applied discourse analysis throughout the research to examine the intention, forming process and consequence of stigmatisation. Naming of the coronavirus is closely associated with the stigmatisation at each phase. Stigmatisation exists at any time and could be especially highlighted by specific opinion formers. Furthermore, the stigmatised targets could also change and switch quickly along with the development of the pandemic. One driving force of such changes in the case of COVID-19 is thought to be the various naming of the virus. Therefore, it can be concluded that an appropriate naming is a fair tool to modify stigmatisation.
\end{abstract}

Keywords: Stigmatisation, COVID-19, Naming Process, Discourse Analysis

\section{INTRODUCTION}

The unexpected COVID-19 pandemic has become one of the hottest and concerned topics at the beginning of the 20 s of the century. First identified in Wuhan, China in late 2019, the local epidemic has turned to national and then global pandemic that caused hundreds of thousands deaths worldwide. While considering the the attack from the virus, a succession of new attacks and conflicts between communities and groups could also be noticed. The mode of interactions between people has changed compared to the post-pandemic period, where the line of 'us' and 'them' has been revealed more clearly. It is noticeable that the way people name the virus has changed within time and space, the social reactions toward different naming in each phase are vigorous and various. Therefore, it is interesting and worthwhile to examine the naming process since the outbreak and the potential impacts on each group and community it has resulted.

In this paper, I used the concept of 'stigmatisation', which is a notion that frequently being used in sociological and anthropological researches, to illustrate and analyse the reactions and actions taken by different social group facing the threat of virus in each phase and their intentions behind. Stigmatisation can also be fashionable as new stigmas would always emerge along with certain social changes, therefore, it is a hot topic among societies that would never be out-of-date. The Discourse Analysis method was adopted throughout the investigation, since it helps to focus on not only the wordings themselves, but also the social, cultural and political intentions behind the language. The data collection was mainly from online mainstream newspapers from different regions, namely China
Daily, South China Morning Post in mainland China and Hong Kong, and CNN, BBC, the Guardian in the Western World. In addition to the official presses, I also gathered the public's response to the pandemic from popular social medias such as Weibo, WeChat (China), Twitter and Facebook.

According to the discoveries found from the research, the stigmatising groups and stigmatised groups are changing within the change in time and the range of the epidemic. This indicates not only that stigmatisation is always existing from the start, but also the fact that it can change and evolve smoothly depending on the development of events. Due to the significant role of language plays on leading social reactions, it has been found out that stigmatisation and naming of the virus complement each other, where both objects stimulate and trigger one another. This has resulted in the wide reflection on how naming matters and how we should name viruses or other health issues with proper names among the societies.

In the first part of the paper, I will examine the previous researches of stigmatisation and and its theoretical motivation, mechanism, and generation process. I will also specifically review issues of stigmas on health issues such as AIDS and Second-hand smoking. Then I would introduce the context of the COVID-19 of its origin, development and corresponding social responses and impacts. After that, I would explain the methods and the data generation process. In the next part I will explain the main findings, following with the final section of conclusion which offers a brief conclusion on the theories used, discoveries and further reflections and possible implications of this research 


\section{LITERATURE REVIEW}

Stigma refers to a mark of social disgrace that arises within social interactions [9], which usually stems from the universal motivation of responding to unknown fear and avoiding threats [5] that posed to people through interacting with other individuals or groups. Stigmatisation can be observed in a broad time and space span since there is a constant division of 'self' and 'other' between communities and groups.

There are mainly three reason why people choose to stigmatise certain objects or social groups. First, to selfprotect. Stigmatisation could be protective as it reminds people to keep away from threats mentally and, hence, physically, the risk of being hurt would be reduced resulted from the reduction in social interaction with stigmatised individuals; Second, to self-strengthening. Stigmatisation could be used to purify and enhance one community's value if it has been challenged, and is therefore often used by leaders to unify group behaviour by strengthening one common belief. Third, to gain social control. The social classification of advantageous and disadvantageous groups would be created through using stigmas to marginalise certain individuals from a community, the advantageous group would get access to power and benefits as a result. Existing studies argues that, the forming mechanism of stigmatisation contains four fundamental phases [1]. The first reaction is labelling: When people identify the threat, they tend to label it according to the Representativeness Heuristic method which originated from people's daily response to risks - people would try to avoid situations they consider as risky. However, such mechanism could easily lead to some obvious deviation. Due to the already formed stereotype that can act as a 'fast track' to stigmatisation, scapegoating and discrimination, the stigmas on certain groups can be further exacerbated [2]. Meanwhile, the stereotypes also cause people's acknowledgement to particular objects less likely to be challenged in any event. [3] The second phase is risk identification and interpretation. The ponderance and impact of one event are determined by anticipation or reports made, one of the key points is the public's familiarity with the risky environment. For instance, if the threat that causes many harms and even deaths originates from smoking or road accidents, which people have already get used to, it would attract a comparatively small range of attention. Conversely, if the threat comes from a relatively unfamiliar system, then people would react with over-imagination and overinterpretation on the risk, thus leading to a higher level of social consequence: stigma. Following the risk identification, the stigma would lead to social avoidance and loss of status of stigmatised groups. When subjects are identified as threats, they would be immediately classified as 'them' rather than 'us', which generates the notion of "outgroup". This would contribute to community or even global-wide avoidance, which drives people to eliminate the risk factors, stay away from the risk sources and isolate the source of transmission. The comprehensive criticism deprives the social opportunities and status, namely stigmatised brands loses their market value, companies lose chances of entering market competition, public figures lose their reputation and even lives and even governments lose their authority. The final step would be cultural adhesion and order re-establishment. The concentrated derogatory and evasive actions from individuals and societies towards the stigmatised object will tend to calm down after a period of time. However, it does not mean that people have forgotten the threat, but they rather store the labels of 'heterogeneous' and 'danger' into their cultural context in order to respond quickly to similar situations in the future. This refers to the ultimate step of the formation of stigmatisation, therefore, in some ways, stigmatisation can be considered as a process of cultural determination of the social order.

From its formation procedure, several key characteristics of stigmatisation can be highlighted. According to Zhang and Tong [1], the primary figure is its destructive effect. The distorted structure of risk identification would fundamentally destroy the image of stigmatised group, giving rise to social, political and cultural chaos. The other two figures are the rapid contamination and non-erasability. The information would be propagated quickly especially under the developed information network nowadays, relevant individuals, industries and even the whole region would be seriously affected in a short period. Also, due to the storage of labelling, the cultural stereotype would eventually develop into fixed values which cannot be removed easily.

Generally speaking, stigmas do not isolate from one another. The interrelationship creates 'multiply stigma', where there are more than one negative labels tagged on a particular group and one may stimulate another one. One common stigmatisation in daily lives related to people's identity, for example, women, impoverished people and minority groups can always be targets. The personal habits and health condition may also be objects to stigmatisation. For example, smoking as a globally rising concern has posed threat to the majority of world population. The smokers, associated with dirt and unclean, have been experiencing social disapproval [4]. Further evidence from the UK shows that, stigma divides into two extents according to the SES and identities of the smokers. For lower SES, female and youth workers, they tend to experience more disapproval from the society compared to higher SES, male and older smokers.

Health issue has been recognised as a common target for stigmatisation, especially those infectious diseases or viruses that could endanger others. The most persuasive example is the stigmatisation on the Sexually Transmitted Diseases (STDs) and the Gay group [5]. STDs in general and AIDS in particular, were considered to be the 'Gay Disease' before the science clarified their origins. The AIDS was considered as a threat to the public safety initially, since people had a fear that they would be infected, and tend to keep distance away from the infected ones as a response. Once they found out the AIDS-infected patients were mainly members of the gay group which had challenge the social norm for a long period, accompanied by the long-lasting stereotypes, the idea of AIDS being associated with gay group had been formed widely. In this 
way, people began to pose graver stigmatisation and further marginalise the targeted social group, causing some ignorant individuals who were members of gay group but not infected suffered from discrimination. The impact of such stigma is overwhelming, where it made the patients harder to get access to treatment as well as the gay members more vulnerable to infection, the reputation of the group has been worsened simultaneously, making them even more difficult to establish themselves in the community. The society has witnessed numbers of similar stigmatisation related to health issues, some would diminish after the scientific evidence became available and some would still exist due to cultural, social and political factors behind. The recent case of COVID-19 can be one of the most proper illustrations of this phenomenon.

\section{CONTEXT}

Coronaviruses are a large family of viruses which may cause illness in animals or humans. The Middle East Respiratory (MERS) and Severe Acute Respiratory Syndrome (SARS) were members of the family and cause severe respiratory infections in humans [6]. The most recently discovered coronavirus in the year 2019 has caused the COVID-19 epidemic, which was an unfamiliar virus that firstly being discovered in Wuhan, China in December 2019 , and has affected most countries worldwide. Its official name, COVID-19, was given by the World Health Organisation on 11 February, where ' $\mathrm{CO}$ ' stands for corona, 'VI' stands for virus, 'D' for disease and '19' for the year of its outbreak. Globally, as of 1 June 2020, there have been more than 6 million confirmed cases of COVID-19, including about 300,000 deaths, reported to WHO. Among the figures, China has occupied 83,022 in total [7] while the United States ranked the first in the number of infection among the rest of the world, which has more than 2 million cases confirmed [6].

People are very likely to catch COVID-19 once they breathe in these fluids from an infected person who carries a large amount of virus. Therefore, it is very essential for people to keep safety social distance, which should be no less than 1 meter from each other [8]. The treatment for most COVID-19 mild-case patients is home-based. For the rest who are the elderly, hospitalisation may be needed [11]. No available vaccines are proved to be effective so far. The widely implementation of social distance has changed the way of socialising. This have had implications on people's daily rituals and the whole society in a macroeconomic perspective. In China for example, the traditional custom of 'paying a New Year call' were forced to be cancelled during the spring festival period. Simultaneously, the number of take-away deliveryman in the nation has risen dramatically, many who lost their jobs due to the virus choosing to take the deliveryman job to make a living for the moment. To prevent the control the spread of COVID-19, a considerable number of countries have adopted 'Lock-down' policies and temporarily cut the connection with the outside world. This has slowed down the pace of globalisation, and made countries which rely on foreign trades severely bruised.

Since the COVID-19 belongs to the Coronavirus family, it is not a completely unknown case for humans. Three coronavirus cases have originated from animal reservoirs over the past twenty years to lead to severe illness and death which spread widely, naming the SARS coronavirus emerged in November 2002, (SARS-Cov), Middle East Respiratory (MERS) emerged in September 2012 and the current SARS-CoV-2 which has declared to be a global pandemic by the World Health Organisation on March, 2020 [12]. The SARS, which firstly identified in Guangdong Province, China, and then spread to the most part of the world by people using air transport, had made more than 8,000 people infected and 800 people died worldwide. It was eventually contained by means of syndromic surveillance, prompt isolation of patients, strict enforcement of quarantine of all contacts, and in some areas community-level quarantine [13]. The MERS, which initially emerged in the Middle East, had affected over 27 countries since 2012 and had overall cases of 2,519 and 866 deaths. According to the WHO, direct or indirect contact with dromedary camels is the most common route of infection, which means the virus was mainly spread from animals to humans and there were relatively less transmissions among people [19]. Despite the fact that all people were aware of the seriousness of MERS-Cov, the perception and practice varied among GCC countries [14]. The majority of people were 'not concerned' or 'slightly concerned' due to their lack of understanding towards the virus their stubbornness to the prevention measures which are not forced to implement.

Compared to the last two pandemics, people's responses to COVID-19 tend to be more rapid. Similar to the MERSCov, the actions each country has taken varies with their state condition, the overall containment measures include quarantine, worldwide curfews and even lock-downs. The lock-down, firstly implemented in China and was initially criticised by the international community of its restriction of freedom, has later been adopted by most of the Asian, Western and African countries. By the end of March, more than 3.9 billion of people were under certain forms of lock-down, that was over half of the global population [15]. The global order has been disrupted to an unexpected direction. Although the international communication on trade and economy has ceased, the cooperation on medical supplies has strengthened. After successfully combating with its local spread of disease, China has taken up its responsibility as the key member of international community and providing as much help as possible to other countries and international organisations [16]. By 27 March, China had provided aids to 89 countries and 4 international organisations. Meanwhile, China had received medical aid from over 21 countries at the outbreak of the disease. 


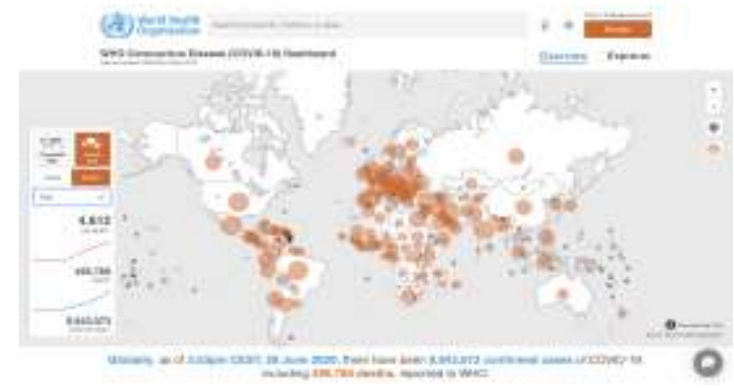

Figure. 1 Source: World Health Organisation

The destructive effect of the COVID-19 can be clearly seen from the infected and death figures, with the previous experience from SARS-Cov and MER-Cov, people are now more aware of the destructiveness of Coronaviruses so they tend to treat it more seriously this time.

Despite the positive international responses, what is also noticeable is the negative reactions over time. As analysed in the Literature Review, stigmatisation created when people have perceived threats from others. COVID-19 as a health threat, which originated from Wuhan and then spread to across China and finally to the whole globe, have resulted in stigmatisation on certain groups from various communities.

\section{METHEDOLOGY}

The method used in this paper is Discourse Analysis, which is the analysis of language as it is used to enact activities, perspectives, and identities [17]. The discourse analysis was originated from Linguistic researches and focused on the logics presented behind languages, which is a broad term for the study of the ways in which language is used between people, both in written texts and spoken contexts. Through the development, it now has been applied to a wider range of researches from sociology, anthropology, psychology, etc. The reason I choose such analysis method is that it could help to pay close attention to the backgrounds of social facts as well as the causes and mechanisms behind the notions, in which it does not only identify words and phrases but also the social, cultural and political context behind them. Therefore, it would be useful for my later analysis on stigmatisation from the worldwide language used throughout the outbreak of COVID19.

The characteristic of Discourse analysis contains six building tasks where we construct context network through language in certain ways at a given period and space [17]. The first section is semiotic building. As Gumperz stated in 1982 [20], languages always contain grammatical clues. These cues guide us to understanding the interaction between commutative, knowledge systems and ways of knowing. Following that is the world building. We build the world through using clues to concentrate on and distinguish "reality" and "illusion", "real" and "unreal", "possible" and "impossible". The next task is activity building, in which to build on understanding towards the activities that are taking place from particular actions. The fourth task is Socioculturally-situated identity and relationship building. This way of building is essential and fit to the stigmatisation issue discussed in this paper. We use clues and cues to comprehend the related interaction between identities and relationships with people's formed attitudes, values, ways of feeling, knowing and believing, as well as ways of acting and interacting with the outside world. The fifth task is political building, in which we use clues to construct multiple "social goods", namely status, power, beauty, humour and property. The final task is connection building, where we make hypothesis about the possible continuous reciprocity between the past, the future, the present and verbally to each other through using clues.

To conclude, Discourse Analysis is about the communication process of turning from Explicit to Implicit through examining assumptions, beliefs, common sense and shared knowledge. It serves to construct meanings and produce essential social orders and power relations. By means of different words and phrases, the effects of language would be different, some would even be distorted. Most written and spoken materials can be targeted to Discourse Analysis: Books, newspapers, brochures, government documents, forums, social media comments, interviews and so on.

To apply such method into my research, I collect data that spans from December 2019 to June 2020 from various sources to archive different views from different sectors. To be more specific, I have gathered relevant news and government reports from domestic presses such as Renwu, South China Morning Post, CCTV news, Xinhua News; and foreign presses such as CNN, the Guardian, the Province and BBC in similar and opposite position in different period, which are comparatively more political-driven. In order to gain an overall comprehensive understanding of the cultural and social background and context at a deeper level, individual posts and comments on social media such as Weibo and WeChat official accounts (China), Facebook and Twitter have also been taken into analysis of the public perception and response to the pandemic and, indeed, other groups who they do not identify as 'us'.

\section{FINDINGS}

Whole naming process, table 1

\begin{tabular}{|c|c|c|}
\hline Time & Naming & Quoted from \\
\hline $\begin{array}{l}2019.1 \\
2\end{array}$ & $\begin{array}{l}\text { Wuhan Virus } \\
\text { Unknown Virus } \\
\text { Huanan Seafood Market } \\
\text { Virus }\end{array}$ & $\begin{array}{l}\text { People's Daily (China), } \\
\text { China Commercial Daily }\end{array}$ \\
\hline
\end{tabular}




\begin{tabular}{|c|c|c|}
\hline Time & Naming & Quoted from \\
\hline 2020.1 & $\begin{array}{l}\text { Wuhan Pneumonia } \\
\text { Wuhan Coronavirus } \\
\text { 2019-nCov } \\
\text { China Virus }\end{array}$ & $\begin{array}{l}\text { South China Morning Post } \\
\text { (HK), } 13 \text { Jan } 2020 \\
\text { - "Wuhan pneumonia: ... } \\
\text { outside China" } \\
\text { The WHO, } 30 \text { Jan } 2020 \\
\text { - "First confirmed cases of } \\
\text { 2019-nCoV ... to Wuhan } \\
\text { City." } \\
\text { The Guardian, } 29 \text { Jan } 2020 \\
\text { - "China virus ... as it } \\
\text { happened" }\end{array}$ \\
\hline 2020.2 & $\begin{array}{l}\text { China Coronavirus } \\
\text { Chinese Virus } \\
\text { American Virus } \\
\text { CIMS virus } \\
\text { COVID-19 [OFFICIAL } \\
\text { NAMING] }\end{array}$ & $\begin{array}{l}\text { The Aljazeera, } 21 \text { Feb } 2020 \\
\text { - "China coronavirus ... } \\
\text { updates" } \\
\text { Chinese non-official we- } \\
\text { media, } 14 \text { Feb } 2020 \\
\text { - "Novel Coronavirus ... } \\
\text { Wuhan?" } \\
\text { World Health Organisation } \\
\text { (WHO) }\end{array}$ \\
\hline 2020.3 & $\begin{array}{l}\text { Chinese Virus [HIGH- } \\
\text { LIGHT POINT] }\end{array}$ & $\begin{array}{l}\text { Donald Trump (President of } \\
\text { the USA) }\end{array}$ \\
\hline 2020.4 & $\begin{array}{l}\text { CCP Virus } \\
\text { Kung Flu }\end{array}$ & $\begin{array}{l}\text { Twitter } \\
\text { Unnamed White House } \\
\text { Official }\end{array}$ \\
\hline
\end{tabular}

\subsection{UNKNOW VIRUS / HUANAN SEAFOOD MARKET VIRUS / WUHAN VIRUS}

The COVID-19 was firstly discovered in Wuhan Huanan seafood market in December, 2019 and firstly identified as an unknown virus. Due to people's natural response to unknown fear and the mainstream media guidance of public opinion, they tend to automatically labelling and identify the risks through simply make Wuhan the whole city as the attribution of responsibility to achieve the purpose of 'self-protect'. Driven by this intention, the corresponding stigmatisation quickly switch to the third phase, the social avoidance and loss of status of Wuhan citizens. Wuhan citizens have become a group of special object to the rest of Chinese public under the national propaganda of 'Fighting, Wuhan!'. The ones who stranded outside the city have been expelled, discriminated and even have their personal information leaked. Though the mainstream media did not show much voice, the negative encounters experienced by Wuhan citizens had been reported by many We-medias

After getting into the taxi, the driver suddenly braked when he got to know that I was from Wuhan. He jumped out of the car, ran to the epidemic centre and ask them, "How can you have a Wuhan man in my car?" He finally accepted to drive me home under the guarantee of the centre staff, but constantly criticising Wuhan people for eating the wild flavour and make the whole nation to take the consequence. [22]

(Renwu Weekly, 2020)

I can understand people's feeling and some of their reactions. But I am still very angry about the leakage of my personal information and people's insane online harassment. [22]

(Renwu Weekly, 2020)

I published information on internet to help people from Wuhan who have no shelter, but I have received unprecedented online harassment and violence everyday since then. Some said to me that I am a stupid crown, some even curse me and my family to die. But what they don't realise is that many of my families are the medical staffs on the front line, they save lives all the time but one of their families is suffering from internet violence only because he is giving a helping hand to the people who desperately need it. [23]

(Renwu Weekly, 2020)

Wuhan people and people who have helped them have been dislodged and isolated from the normal social life. Under the overall context, they have been closely associated with the 'Seafood Market Virus' and 'Wuhan Virus', avoided by the rest of the Chinese society and have their basic social rights lost as well. This can be commonly seen since people would always tend to avoid and expel peculiar things to maintain 'status quo' in a stable society. Such disturbance on routine can have serious effects on groups. The inner mental injury is the most obvious consequence on the stigmatised people, while the outer influence can be either further division between community members or limited access to public goods and most importantly, healthcare. Residents who live nearby the seafood market were rejected by hospitals at the beginning of the outbreak due to their identity and potential risk of infection.

I feel lucky that I did not tell the truth when I went to the hospital. One of my daughter's friends who have been working in the hospital said that they wouldn't have accepted me if I told them I worked in Huanan Seafood Market. [21]

(Sanlian Jounral, 2020)

These stigmas would not disappear with the recovery of patients. Their lives would not back to normal since the public's fear on the virus has been distorted, since even the recovered patients are considered to be viruses as well. In some way, humanity is even more terrible and destructive compared to the virus, and this can clearly explain that stigmatisation are created through words and sentences. I started to feel guilty when I recovered and back home. My families are trying to keep distance with me all the time. Even breathing feels like a sin. [21]

(Sanlian Journal, 2020) 
The physical illness may have been cured, but the mental illness comes along and can hardly be removed. Some patients may not die from the virus, but die from suicide caused by discrimination from the surrounding. Therefore, it can be concluded that the pandemic and the social stigmatisation together have had a long shadow to the patients that could hardly be erased.

The transformation has also led to a series of order reestablishment, which refers to the ultimate stage of stigmatisation. The 'health code' system has been fully adopted across the nation, citizens' daily information such as travel records and health conditions have been collected in real time to cover entrance permission into public areas [24]. Another significant measure for prevention and control was the restriction on Wuhan people for entering Beijing which was not lifted until 6 June. The order reestablishment can be temporary and relatively short-lasting compared to Cultural Fixation. Although it is yet to completely fixed, the consequence can be anticipated from the past experience of the SARS-Cov. The Cantonese are now stereotyped for their notorious image of "eating everything', the statement is largely spread and fixed since the outbreak of SARS in 2003 from a man eating civets with viruses. Therefore, similar impression on Wuhan people can be estimated to be solidified in people's mind even decades after.

\subsection{CHINA VIRUS / NCP / COVID-19}

A statistic analysis [25] has shown that in the early phase of the outbreak where the local epidemic had yet to turn to global pandemic, Western reports on the virus were mainly negative because of their uncertainty to this. While the names such as 'Wuhan virus' has been widely spread throughout China, 'Chinese Virus' emerged in the international community as well. From 21 January, such naming has appeared on several mainstream online newspapers, namely the CNN, the South China Morning Post (SCMP) and the Province in Canada. Before the World Health Organisation published the official name of COVID-19, the various namings of the virus were reasonable since these were mainly for the purpose of convenience. In addition, the name of 'Chinese Virus' might also originate from people' pre-formed stereotypes on Chinese people about their eating pattern from decades ago.

My parents, like many Chinese immigrants, operated restaurants in Houston for most of their lives...One day, my mom asked one of our waitresses whether her parents would like to come for dinner. "Oh, no, ma'am," she replied. "I asked, but my father said he wouldn't eat at any place run by Chinese. You can't trust what they will try to pass for meat." That sad stereotype continues to exist today, amplified by concerns over the origins of the coronavirus outbreak in Wuhan, China. [30]

Douglas Wong, 2020
Therefore, from the above statement by an American, the naming at this phase was mainly driven by social factors without the intervention of political elements.

\subsection{CHINESE VIRUS [HIGHLIGHT POINT] / AMERICAN VIRUS}

After the official names of Novel Coronavirus Pneumonia (NCP) and COVID-19 was determined in 7th and 11st of February by the National Health Commission of the PRC and World Health Organisation respectively, not all presses and sectors have fully adopted immediately. It was not until Donald J. Trump, the president of the United States, and several of his Republican allies repeatedly using the 'Chinese Virus' at a press conference on 17th March when the term began to be widely discussed globally. Trump, as one of the key opinion formers, had successfully divert the public's attention during the period when the local Chinese epidemic turned to the global pandemic and seriously affected the United States. His action shows the attempts of gaining social control and unify the community value in the stigmatisation process. And this unavoidably have many relations with the present international situation. China has risen to the second largest economy in the world, which ranks only second to the USA, and has therefore became the conspicuous threat to the latter.

But the coronavirus crisis is likely to have a lasting impact, especially when it reinforces other trends that are already undermining globalisation. It may deal a blow to fragmented international supply chains, reduce the hypermobility of global business traveler, and provide political fodder for nationalists who favour greater protectionism and immigration controls. [26]

Philippe L, 2020

Trump has devoted himself to the work of de-globalisation to suppress China's quick development. Moreover, due to the standing divergence of ideology, the actions taken by the Chinese government such as lock-down could be interpreted as a step away from freedom, and therefore could be used as a tool to guide public opinion and to further solidify the value of Western society.

Associating the virus with foreigners also plays to his supporters' cognitive bias against outsiders and immigrants and their fear of contagion - racial, social, cultural or otherwise. [27]

The Conversation, 2020

To respond to critics from various circles, President Trump simply used the following statement to explain his intention:

Because it comes from China. It's not racist at all, no. It comes from - China. That's why. It comes from China. I want to be accurate. [28] 
In addition, Trump claimed that he was intended to attach "China" to the virus to combat with a disinformation campaign of 'American Virus' promoted by Beijing officials and Chinese alternative media that the American militants who participated in the 7th CISM Military World Games held in Wuhan were the source of the outbreak. This mutual blaming game between China and the USA originated from the stigmatisation on each other, and was the competition of scapegoating as well as between opinion formers. Actively responding to the call of president Trump and the guidance of mass media, stigmatisation and discrimination on China becomes even more vigorous. There have been numerous reports of British and American Asians being attacked mentally and physically by the locals while the coronavirus spreads in the Western world.

Went to take out trash. Was talking on phone in Chinese.

Man walked by on sidewalk \& in interest of social distancing, I said, "sorry, go ahead." "FUCKING CHINESE,"he yelled loud enough I could hear hime over aide's voice on phone.

Twitter, 2020

In New York City, a man assaults a woman wearing a face mask, calling her a "diseased $b^{* * * * . " ~ O n ~ a ~ L o s ~ A n g e l e s ~}$ subway, a man proclaims Chinese people are filthy and says "every disease has ever came from China." Rampant ignorance and misinformation about the novel coronavirus, experts say, has led to racist and xenophobic attacks against fellow Americans or anyone in the US who looks East Asian. [30]

\section{Holly Y, Natasha C, Dushyant N, CNN, 2020}

A number of European governments have rejected Chinese-made equipment designed to combat the coronavirus outbreak. Thousands of testing kits and medical masks are below standard or defective, according to authorities in Spain, Turkey and the Netherlands...Dutch officials said that the masks did not fit and that their filters did not work as intended, even though they had a quality certificate. [31]

BBC, 2020

\subsection{EXPORTING AND IMPORTING}

The international status of Chinese people have been further weakened during the period, the accompanying stigmatisation, based on the previous stereotypes and the current epidemic, is becoming increasingly fierce. Numerous critics and questions have pointed to the Chinese government, the Chinese people outside the country and even the medical apparatus and instruments made in China. The international order has changed correspondingly. The health crisis, accompanied by the economic and humanitarian crisis, have resulted in a global chaos that might reverse the current international situation. The lock-down of global cities, mutual stigmatisation between China and the USA and the policy of air suspension have increased the difficulty of cooperation and understanding between countries, making the future of globalisation more unpredictable.

Simultaneously, within the spread of the pandemic in the globe, the groups being stigmatised switch and increase all the time. A number of Chinese students and citizens studying and living abroad began to rush going back to China to find better shelter. However, as the time goes by, they did not receive the treatment from the domestic Chinese public as politely as they expected. There has been a considerable long period of history of stereotypes on the overseas students in which they are considered to be rich, arrogant and ignoramus. Although these do not represent the whole group, the labels have been further confirmed in people's mind during the period. On March 11, an Italian born Chinese posted a video on the internet, complaining about the strict epidemic prevention and control measures, "this is how you treat people who back from Europe"; On March 16 , a short video of a female student who studies in Italy insisted on drinking mineral water at a central quarantine site attracted the attention of the public. Another Australian Chinese refused to go out for a running with a mask in accordance with the regulations after returning to Beijing, and yelled "help! Harassment!" when the staff trying to persuade her. The video caused a heated debate on the internet. The already existed negative impression upon, added with the unreasonable behaviours by a few members, have intrigued the domestic passion on the group. Before the series of incidents, the tone of comments on Chinese people living abroad are negative but mainly concerned:

Do not come back, do not come back, do not come back. And stay safe outside.

Huangye. (Weibo, 2020)

However, after the incidents occurred, people's attitude turns more aggressive from self-protection. Their direction of criticism has turned from the events itself to the group as a whole.

Stop pretending. (Don't) Paying tax for America and come poisoning China. Do not come back, we do not welcome you.

Anonymous. (Weibo, 2020)

Such attacks are built on 'multiple stigmas' towards the overseas Chinese group. The existing stereotypes mix with the worse reputation made by the minority, made the group in a dilemma during the difficult time. The media has played a vital role as well. The propaganda such as "ungrateful fools" have made the public more emotional. What people are ultimately stigmatising is mainly individuals but not the behaviours they do. The relevant policies made by the Chinese government such as "Five-One Policy", which refers to "One air company, one country, one airline, one week and one time", have been adopted to limit the number of passengers travelling from and to the country. This policy has strictly reduced the air seats available, making the overseas' Chinese people harder to go back. Moreover, the image of overseas Chinese in the 
mind of domestic Chinese public would be further deteriorated while the foreign stereotype of Chinese people eating wildlife would be consolidated to a higher degree.

Until now, we have seen how different agents and sector show their stigmatisation through the ways of naming the virus. The intentions, process, impact and consequences have all been fairly analysed and evaluated in this part.

\section{CONCLUSION}

In this paper, I have mainly used Discourse Analysis to investigate on the written texts related to worldwide people's attitudes on COVID-19 crisis from various media platform such as online newspapers and mass social medias. The research has suggested that during the pandemic period, people tend to take common actions to try to stay away from threats of the virus. One major way is to expel certain groups from their communities through stigmatisation and even use corresponding violence if needed. Within the change in time and the range of the epidemic, the stigmatising groups and stigmatised groups are changing over time as well. From stigmas on "Huanan Seafood Market" merchants, Wuhan citizens and then to Chinese people and Chinese Overseas students, the stigmatisation consistently exist in different phases and usually shift swiftly according to the development of events. From the development process of the name "Chinese Virus", it can be seen that the stigmas are smoothly alive, but it needs a highlight moment or one or more key opinion formers to make it widely spread, and such turning point might make the the property of stigmas change from social-driven to political or even racial-driven.

Wording always matters since it can directly convey people's thoughts, feelings and intentions. Analysing languages is therefore a strong tool to be used throughout the research. Meanwhile, the events and analysis in this paper have been closely discussed with relevant theories, which can be a relatively good combination of theoretical knowledge and real-life application. However, due to the very limited time available to conduct investigation, the types of data collected were only restricted to news reports and social media posts. More methods of data collection and analysis would be developed in this paper if having more time and efforts.

Through the paper, it can be said that stigmatisation and naming are the process of mutual reinforcement. The inappropriate naming would generate and solidify stigmatisations and stigmas would reversely affect the way people name the virus. This vicious circle has obstructed the collaboration between countries and even exacerbated international relations in some ways. Therefore, it could be suggested that the names of viruses in the future should be more carefully considered in order to prevent the creation of stigmas to the largest extent. The World Health Organisation has working on determining the most proper name to call each virus since decades ago, however, it still needs to improve its efficiency and influence in a global scale to uniform the correct name and, more importantly, the correct value.

\section{REFERENCES}

[1] Le Z. and Xing T. ( unknown date of publishment). Stigmatisation: deep explanation and analysis on the consequences of emergencies. [Online] [Accessed 21 May. 2020]

[2] Fiske S. T. (1993). Controlling other people. The impact of power on stereotyping. [Online] [Accessed 18 May. 2020]

[3] Tindall B. and Tillett G. (1993). HIV-related discrimination. AIDS 4. [Online] [Accessed 20 May. 2020]

[4] Hannah R. F. And Helene J. (2006). Pollution, Peril and Poverty: a British Study of the Stigmatisation of smokers. [Online] Available at: Journal of Community \& Applied Social Psychology, p. 481-491. [Accessed 25 May. 2020]

[5] Norbert G. And Margaret A. S. (1994). Stigmatisation, Scapegoating and Discrimination in Sexually Transmitted Diseases: Overcoming 'them' and 'us'. [Online]

[6] Who.int, (2020). Q\&A on coronaviruses (COVID19). [online] Available at:

https://www.who.int/emergencies/diseases/novelcoronavirus-2019/question-and-answers-hub/q-adetail/q-a-coronaviruses [Accessed 2 Jun. 2020]

[7] Weekly.chinacdc.cn, (2020). Tracking the Epidemic. [online] Available at:

http://weekly.chinacdc.cn/news/TrackingtheEpidemic.h tm [Accessed 2 Jun. 2020]

[8] Who.int, (2020). WHO Coronavirus Disease (Covid-19) Dashboard. [online] Available at: https://covid19. who.int/?gclid=CjwKCAjw8df2BRA3E iwAvfZWaMK54TY7vSKv0GsmAGhyTwtTP_7pIZee OT7qYnPDWiuLgdH1iEQuZRoCnRQQAvD_BwE [Accessed 2 Jun. 2020].

[9] Goffman, E. (1963) Stigma: Notes on the management of spoiled identity. Prentice Hall, Englewood Cliffs.

[10] Huang C, Wang Y, Li X et al. (2020) Clinical features of patients infected with 2019 novel coronavirus in Wuhan. China. The Lancet 2020; 395: 497-506.

[11] Johns Hopkins Bloomberg School of Public Health, Centre for health security. (2020). Coronaviruses: SARS, MERS, and 2019-nCoV. [online] Johns Hopkins Center for Health Security, center- 
forhealthsecurity.org. p. 1-2. Available at: https://www.centerforhealthsecurity.org/resources/COV ID-19/index.html [Accessed 3 Jun. 2020].

[12] National Institute of Allergy and Infectious Disease, (2020). Coronaviruses. [online] Available at:https://www.niaid.nih.gov/diseases-

conditions/coronaviruses [Accessed 3 Jun. 2020].

[13] Annelies, S, Calvin, C, Vernon, L. (2020). Can we contain the COVID-19 outbreak with the same measures as for SARS? 1st ed. [pdf] London WC1E 7HT, UK. Available at https://www.thelancet.com/action/showPdf?pii=S14733099\%2820\%2930129-8 [Accessed 4 Jun. 2020].

[14] Amani A, Harunor R, Mada B, Tariq A, Nasser B. (2016) Public response to MERS-CoV in the Middle East: iPhone survey in six countries. Journal of Infection and Public Health 10, [online] p. 534-540. Available at:

https://reader.elsevier.com/reader/sd/pii/S18760341173 00278?token=469FA3F119A8FE659C13EA2A62A69E 01D42CC4881FC4E687AAB2B3F1C775361BEEDF8 23175DEAC35292ED1EC3B7D4A1A. [Accessed 6 Jun. 2020]

[15] Alasdair, S. (2020). Coronavirus: Half of humanity now on lockdown as 90 countries call for confinement. Euronews, [online] p. 1. Available at: https://www.euronews.com/2020/04/02/coronavirus-ineurope-spain-s-death-toll-hits-10-000-after-record-950new-deaths-in-24-hou [Accessed 9 Jun. 2020]

[16] Geng, S. (2020) Taking part in international cooperation to show the Chinese responsibilities. In: Foreign Ministry News Conference. [online] City: Beijing. Available at: https://m.sohu.com/a/382368188_188589 [Accessed 9 Jun. 2020]

[17] James, G. (1999). An Introduction to Discourse Analysis_Theory and Method. 2nd ed. [ebook] London: Routledge. [Accessed 1 Jun. 2020].

[18] Richard, N (2020). Understanding the Use of Language Through Discourse Analysis. [online] ThoughtCo.com. Available at: https://www.thoughtco.com/discourse-analysis-or-da1690462 [Accessed 1 Jun. 2020].

[19] Yella, M. (2020). How do SARS and MERS compare with COVID-19? [online] Available at: https://www.medicalnewstoday.com/articles/how-dosars-and-mers-compare-with-covid-19
[20] Gumperz, J. J. (1982). Discourse strategies. Cambridge: Cambridge University Press.

[21] Wang, Zhang. (2020). It is more realistic to treat Wuhan citizens kindly than shouting the propaganda of 'fighting, Wuhan'. In: Sanlian Daily Magazine. [online] [Accessed 24 Jun. 2020].

[22] Renwu. (2020). I am most worried about the mental injuries of Wuhan citizens during this period. In: Renwu Daily Magazine. [online] [Accessed 24 Jun. 2020].

[23] Renwu. (2020). The first recovered patient in Jinzhou who used to work in Huanan Seafood Market says, I am the lucky one . In: Renwu Daily Magazine. [online] [Accessed 24 Jun. 2020].

[24] Xinhua News. (2020). Tencent led the drafting of the first "Epidemic prevention travel code" team standard, to help the epidemic prevention and control and resumption of work and production. [online] Available at:

https://baike.baidu.com/reference/24365975/54e9zHna W5Awd44LaWl-eanzuF8-iHfE-

K5VzXeyVgTm6B14uKXbsB06WSToAoigyQWqmEseWX1lmEdi7yn78x_qV_JpE1zsZvDRH9416aqZ1F ecaY [Accessed 25 Jun. 2020].

[25] THUIR. (2020). How the western media think of Covid-19 preventions and controls? Empirical emotional analysis based on 260,000 news reports. [online] Available at: https://mp.weixin.qq.com/s/hpL9kArDvx2crxGcFJC_Y Q [Accessed 25 Jun. 2020].

[26] Philippe L. (2020). The Coronavirus Is Killing Globalization as We Know It. Foreign Policy. [online] Available at:https://foreignpolicy.com/2020/03/12/coronaviruskilling-globalization-nationalism-protectionism-trump/ [Accessed 26 Jun. 2020]

[27] The Conversation. (2020). Donald Trump's 'Chinese virus': the politics of naming, [online]. Available at: https://theconversation.com/donald-trumpschinese-virus-the-politics-of-naming-136796. [Accessed 24 Jun. 2020]

[28] The Guardian. (2020). 'Not racist at all': Donald Trump defends calling coronavirus the 'Chinese virus' video, [online]. Available at:

https://www.theguardian.com/world/video/2020/mar/18 /not-racist-at-all-donald-trump-defends-calling- 
coronavirus-the-chinese-virus-video [Accessed 24 Jun.

2020]

[29] Douglas, W. (2020). Eating Chinese food in the age of coronavirus. The Washington Post, [online]. Available at:

https://www.washingtonpost.com/nation/2020/01/30/eat ing-chinese-food-age-coronavirus/\#comments-wrapper. [Accessed 25 Jun. 2020]

[30] Holly Y, Natasha C, Dushyant N. (2020). What's spreading faster than coronavirus in the US? Racist assaults and ignorant attacks against Asians. CNN, [online] Available at:

https://edition.cnn.com/2020/02/20/us/coronavirusracist-attacks-against-asian-americans/index.html [Accessed 20 Jun. 2020]

[31] BBC. (2020). Coronavirus: Countries reject Chinese-made equipment. [online] Available at: https://www.bbc.co.uk/news/world-europe-52092395

[Accessed 21 Jun. 2020] 